\title{
Tinjauan Artificial Intelligence untuk Smart Government
}

\author{
Saluky \\ Sekolah Teknik Elektro dan Informatika \\ Institut Teknologi Bandung \\ luke4line@gmail.com
}

\begin{abstract}
Higher population growth and urbanization to seek a better life keep the city's population increasing and if not controlled it is estimated that by 2030 it will reach $70 \%$ of the urban population. The higher the population then the service to the community must be further enhanced because the city's problems will be more complex. The ability of government to adapt to all changes requires artificial intelligence in order to process the data obtained, understand and provide effective and efficient actions in order to serve all its citizens. The result of this survey study is to present artificial intelligence techniques such as search, reasoing, planning, and learning. Artificial intelligence method that is widely used is artificial neural network to solve the problem.
\end{abstract}

Keyword--Artificial Intelligence, Government

\section{PENDAHULUAN}

A. Latar Belakang

Pertumbuhan kota yang terus berkembang dimulai dengan fenomena urbanisasi pada akhir abad dua puluh. Sejak saat itu, semakin banyak orang pindah dari daerah pedesaan ke perkotaan untuk mendapatkan kesempatan kerja, pendidikan, perumahan, dan transportasi yang lebih baik[1][2]. Pada tahun 2010 50\% penduduk dunia tinggal di perkotaan dan jika tidak dikendalikan diperkirakan pada tahun 2030 dapat mencapai $70 \%$ penduduk yang tinggal di kota. Oleh karena itu, sangat penting bagi kota-kota untuk siap melayani jumlah warga yang besar ini dan menghadapi tantangan baru (mis., kemacetan lalu lintas, polusi udara, pengelolaan limbah, pemantauan air, dan sebagainya)[3]. Dalam konteks ini, teknologi informasi dan komunikasi (TIK), bersama dengan pemerintah daerah dan perusahaan swasta, memainkan peran kunci dalam menerapkan solusi, layanan, dan aplikasi inovatif untuk menjadikan kota cerdas sebagai kenyataan[4].

Kota cerdas menghasilkan data yang sangat besar, realtime dan bervariasi atau yang disebut big data[5] dari data tersebut berasal dari pergerakan orang dan material dalam hal aliran keputusan tentang bentuk fisik dan sosial kota. Kota dapat disebut pintar jika ada fungsi intelijen yang mampu mengintegrasikan dan mensintesis data yang sangat besar ini ke beberapa tujuan serta mengetahui cara meningkatkan efisiensi, kesetaraan, keberlanjutan dan kualitas hidup di kota.[4][6][7]. Untuk mencapai layanan personal yang sukses, dua kebutuhan mendasar dibutuhkan yaitu pertama adalah kemampuan untuk memahami perilaku pengguna dan yang kedua adalah kemampuan untuk beradaptasi secara efisien, terhadap perilaku pengguna yang berubah dari waktu ke waktu. Kecerdasan Buatan/Artificial Intelligence (AI) dalam berbagai kebutuhan umumnya digunakan dalam aplikasi untuk memahami dan menyesuaikan perilaku pengguna, namun sementara sistem ini cenderung bekerja dengan baik di domain tertentu atau permasalahan yang sangat spesifik, pencarian untuk kecerdasan buatan yang dapat menyelesaikan banyak masalah masih dalam level konsep[8]. Sampai saat ini, AI telah dikembangkan dalam berbagai bentuk dan berhasil diterapkan di berbagai bidang, termasuk bidang penerbangan, ilmu komputer, keuangan, pendidikan, perawatan kesehatan, kedokteran, transportasi, industri dan sebagainya. Ini menyediakan berbagai algoritma, teori, metode dan menawarkan potensi besar untuk mengubah teknik pembuatan saat ini di bawah situasi penyimpanan data yang terus meningkat. Sebagai contoh, machine learning (ML) adalah salah satu perwakilan AI, yang memungkinkan mesin untuk belajar dan memperbaiki secara mandiri[9]. Menerapkan ML di bidang manufaktur dapat memperoleh informasi yang berguna dari kumpulan data yang ada, sehingga memberikan dasar untuk perkiraan atau prediksi untuk mengoperasikan mesin dengan perilaku masa depan seperti pembuatan keputusan dan perbaikan sistem otomatis. Hal ini juga bermanfaat untuk mendeteksi pola tertentu atau menjelajahi keteraturan dalam lingkungan manufaktur yang dinamis[10]. Dari latar belakang akan direview hasil penelitian kecerdasan buatan yang telah diterapkan dalam pemerintah (government). 


\section{B. Rumusan Masalah}

Dengan semakin banyaknya penduduk kota maka kebutuhan layanan semakin bertambah dan semakin kompleks, untuk memberikan pelayanan terhadap penduduk kota dibutuhkan suatu model layanan yang dapat membantu memberikan informasi secara mandiri sehingga mempermudah pemangku jabatan untuk mendapatkan informasi, perencanaan, dan melakukan kebijakan.

\section{II.TINJAUAN PUSTAKA}

\section{A. Artificial Intelligence}

Kecerdasan buatan (AI) dapat didefinisikan sebagai cabang ilmu komputer yang berkaitan dengan otomasi perilaku cerdas[11]. Atau difinisi lain AI adalah pemrograman komputer untuk melakukan tugas yang biasanya membutuhkan kecerdasan manusia[12]. Ini termasuk kemampuan untuk memahami dan memantau informasi secara visual/spasial, pendengaran, alasan, membuat prediksi, berinteraksi dengan manusia dan mesin, dan terus belajar serta memperbaiki diri. Sementara data dan analisis yang besar dapat digunakan untuk menyelesaikan beberapa tugas yang sama seperti AI, termasuk otomasi, AI tidak identik dengan persyaratan ini. Al menjadi kuat dengan pembelajaran mesin, di mana komputer belajar dari pelatihan dan masukan yang diawasi seiring waktu untuk memperbaiki respons. Misalnya, terjemahan, pengenalan wajah, dan iklan online bertarget bisa menjadi aplikasi pembelajaran mesin. Salah satu skenario di mana pembelajaran mesin bisa menjadi berharga dalam konteks pemerintah adalah ketika ada banyak data namun tidak cukup banyak orang untuk mengelolanya atau para ahli untuk menganalisanya. Skenario lain adalah proses rutin yang bisa dilakukan mesin secara otomatis sambil memperbaiki seiring berjalannya waktu. Melalui aplikasi ini, AI dapat mengurangi beban administrasi, membantu mengatasi masalah alokasi sumber daya, dan melakukan tugas yang kompleks secara signifikan. Aplikasi AI untuk layanan warga juga bisa mengurangi biaya. Diperkirakan bahwa otomatisasi tugas pegawai pemerintah bisa dihemat[12][13].

Agar komputer bisa bertindak seperti dan sebaik manusia, maka komputer juga harus diberi bekal pengetahuan dan mempunyai kemampuan untuk menalar. Untuk itu AI akan mencoba untuk memberikan beberapa metoda untuk membekali komputer dengan kedua komponen tersebut agar komputer bisa menjadi mesin pintar[14]. Lingkup utama kecerdasan buatan:

- Natural Language Processing(NLP) cabang ilmu komputer dan linguistik yang mengkaji interaksi antara komputer dengan bahasa (alami) manusia. NLP sering dianggap sebagai cabang dari kecerdasan buatan dan bidang kajiannya bersinggungan dengan linguistik komputasional. Kemajuan dibidang ini membuat komputer dapat melakukan penerjemahan dari satu bahasa manusia ke bahasa manusia yang lain. Inti pengolahan bahasa alami ada dalam parser. Parser adalah bagian yang membaca kalimat dari bahasa sumber dan menguraikan serta menganalisis kata-kata yang terdapat di dalam kalimat tersebut dan mencocokkan dengan tata bahasa yang benar. Pendukung parser adalah kamus yang berisis kosa kata. Keluaran parser akan diproses oleh bagian yang disebut representasi pengetahuan, yang berperan dalam mengartikan kalimat masukan. Pada aplikasi penerjemahan,setelah makna kalimat diketahui bagian penerjemah keluaran akan menghasilkan keluaran berupa teks dalam bahasa alami.

- Knowledge Representation(KR) adalah suatu proses untuk menangkap sifat-sifat penting pada sebuah permasalahan dan membuat informasi tersebut dapat diakses oleh prosedur pemecahan permasalahan

- Automated Reasoning(AR) Penalaran otomatis merupakan bidang ilmu komputer dan logika matematika didedikasikan untuk memahami berbagai aspek penalaran.

- Machine Learning(ML) adalah sebuah cabang dari kecerdasan buatan, Inti dari mesin belajar berkaitan dengan representasi dan generalisasi

- $\quad$ Computer Vision(CV) adalah bidang yang mencakup metode untuk memperoleh, mengolah, menganalisis, dan pemahaman gambar dan, secara umum, data dimensi tinggi dari dunia nyata untuk menghasilkan informasi numerik atau simbolis, misalnya dalam bentuk keputusan.

- $\quad$ Robotic(R) adalah cabang dari teknologi yang berhubungan dengan desain, konstruksi, operasi, dan aplikasi robot.

Untuk penyelesaian kecerdasan buatan mempunyai 4 teknik sebagai berikut :

- Searching(teknik pencarian) yaitu teknik penyelesaian masalah yang mempresentasikan masalah ke dalam ruang keadaan(state) dan secara sistematis melakukan pembangkitan dan pengujian state-state dari initial state sampai ditemukan suatu goal state. 
- Reasoning(teknik penalaran) yaitu teknik penyelesaian masalah yang mempresentasikan masalah masalah ke dalam logic (mathematics tools yang digunakan untuk mempresentasikan dan memanipulasi fakta dan aturan).

- Planning(Perencanaan) suatu metode penyelesaian masalah dengan cara memecahkan masalah ke dalam sub - sub masalah yang lebih kecil, menyelesaikan masalah satu demi satu, kemudian menggabungkan solusi solusi dari satuan terkecil menjadi konfrehensif.

- Learning Secara otomatis menerapkan aturan yang diharapkan bisa berlaku umum untuk data-data yang belum pernah kita ketahui.[11]

\section{B. Smart City}

Sangat banyak sekali defenisi tentang kota cerdas, Konsepnya telah digunakan di seluruh dunia dengan nama yang berbeda, konteks dan makna. Berbagai varian konseptual dihasilkan dengan mengganti kata smart dengan kata sifat seperti digital atau cerdas yang mudah digunakan dan digunakan kembali. Ada yang mengakui penggunaan kota cerdas sebagai sebuah fenomena pelabelan perkotaan[15]. Berikut ini beberapa definisi dari smart city :

- Sebuah kota berperforma baik dalam indikator ekonomi, manusia, pemerintahan, mobilitas, lingkungan, dan hidup, dibangun di atas kombinasi cerdas dan warga kota yang mandiri dan mempunyai tingkat kesadaran yang tinggi[16].

- Sebuah kota yang memonitor dan mengintegrasikan kondisi dari semua Infrastruktur kritisnya, termasuk jalan, jembatan, terowongan, rel, kereta api, bandara, pelabuhan, komunikasi, air, listrik, bahkan bangunan besar, dapat lebih mengoptimalkan sumber dayanya, rencanakan pencegahannya, kegiatan pemeliharaan, dan memantau aspek keamanan sambil memaksimalkan layanan kepada warganya[17].

- Sebuah kota yang menghubungkan infrastruktur fisik, IT infrastruktur, infrastruktur sosial, dan infrastruktur bisnis untuk memanfaatkan kolektif kecerdasan kota[18].

- Penggunaan teknologi Smart Computing untuk membuat komponen dan layanan infrastruktur penting sebuah kota yang meliputi administrasi kota, pendidikan, kesehatan, keselamatan umum, real estat, transportasi, dan utilitas - lebih cerdas, saling berhubungan, dan efisien[19].

Pengembangan kerangka kerja integratif untuk menjelaskan hubungan dan pengaruh antara faktor-faktor dalam inisiatif kota cerdas. Masing-masing faktor ini penting untuk dipertimbangkan dalam menilai tingkat kota cerdas dan saat memeriksa prakarsa kota cerdas. Faktor-faktor tersebut menjadi dasar untuk membandingkan bagaimana kota membayangkan inisiatif cerdas mereka, menerapkan layanan bersama, dan tantangan yang terkait. Kumpulan faktor ini juga disajikan sebagai alat untuk mendukung pemahaman tentang keberhasilan relatif berbagai prakarsa kota cerdas yang diterapkan dalam konteks yang berbeda dan untuk tujuan yang berbeda. Demikian pula, kerangka kerja ini dapat membantu untuk menguraikan dampak aktual pada jenis variabel (organisasi, teknis, kontekstual) terhadap keberhasilan prakarsa kota cerdas[20].

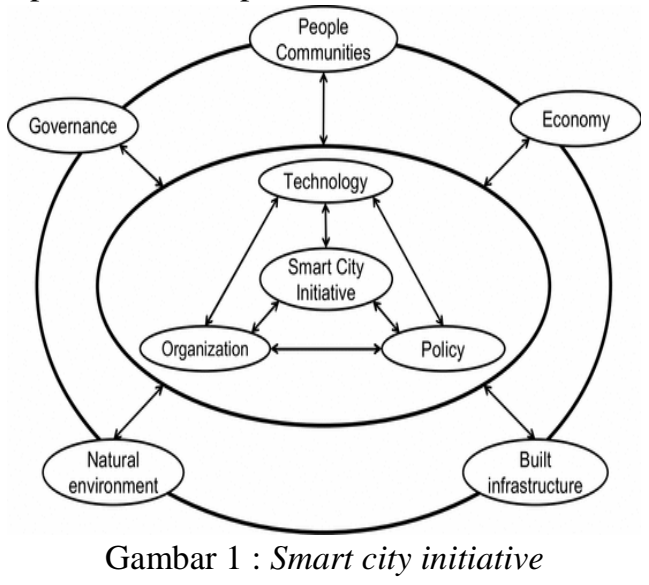

Pengembangan framework smart city yang digagas oleh smart city community inovation center untuk mengukur maturity sebuah kota disebut Garuda Smart City Maturity Model mengambil tiga aspek (economy, environment, social community) dari sustainability development sebagai cluster yang akan dimunculkan. Ketiga cluster tersebut ditambah dengan ICT. Dalam konsep smart city, ICT dipandang sebagai enabler. Penggunaan ICT memungkinkan sebuah kota untuk memperbaiki kinerja ketiga aspek yang lain. 


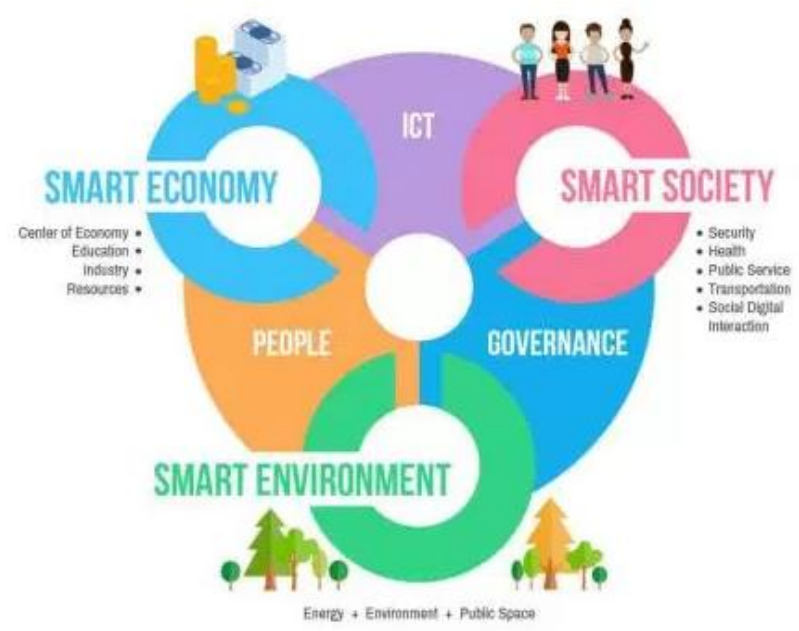

C. Smart Government

Gambar 2 : Garuda Smart City Model

Smart Government merupakan pengelolaan proses bisnis yang berkaitan dengan pemerintahan dan administrasi dengan bantuan teknologi informasi dan komunikasi(ICT). Tata kelola sistem informasi yang saling berhubungan dan terintegrasi bertujuan untuk meningkatkan kinerja dalam melakukan tugas dan fungsi pelayanan publik yang lebih efektif dan efisien. Ini termasuk portofolio e-government dan open government, merangkul data besar dan data terbuka. Intinya, ini tentang tindakan pemerintah dan administratif yang berkelanjutan di era IoT, Definisi ini mencakup tingkat lokal atau kotamadya, tingkat regional atau provinsi, tingkat nasional serta tingkat internasional dan global. Termasuk inilah keseluruhan sektor publik, yang terdiri dari legislatif, eksekutif dan yudikatif serta perusahaan publik[21].

Pemerintah menggunakan e-Governance untuk meningkatkan efisiensi, dan efektivitas sistem administrasi publik dan pemberian layanan. Sifat digital yang dinamik memberi kesempatan kepada negara-negara berkembang untuk sepenuhnya menerima e-Governance(eGov), yang pada akhirnya akan berkontribusi memenuhi kebutuhan dan melayani warganya[22].

Pengembangan digitalisasi pemerintahan atau yang disebut eGovernment melibatkan komponen yang berbeda yang cenderung saling terkait. Mengabaikan keterkaitan komponen ini bisa berujung pada kegagalan komponen lainnya, maka kebutuhan untuk integrasi. Contoh komponen yang perlu termasuk siklus hidup proyek, penilaian dampak, pemantauan, dan evaluasi. Ini penting untuk dicatat bahwa tidak ada evaluasi yang efektif terhadap pengembangan e-Gov bila ada tidak ada monitoring dan evaluasi Oleh karena itu, pembentukan pemantauan yang tepat Mekanisme sangat penting karena data dikumpulkan selama fase pemantauan akan digunakan untuk tujuan evaluasi[23].

\section{Internet of Things}

Untuk mendapatkan data dari lingkungan digunakan teknologi Internet of things untuk saling berkomunikasi[24][25]. Internet of Thing (IoT) adalah sebuah konsep dimana suatu objek yang memiliki kemampuan untuk mentransfer data melalui jaringan tanpa memerlukan interaksi manusia ke manusia atau manusia ke komputer. IoT telah berkembang dari konvergensi teknologi nirkabel, micro-electro mechanical systems, dan Internet. "A Things" pada Internet of Things dapat didefinisikan sebagai subjek misalkan orang dengan monitor implant jantung, hewan peternakan dengan transponder biochip, sebuah mobil yang telah dilengkapi built-in sensor untuk memperingatkan pengemudi saat ada komponen yang tidak sesuai. Sejauh ini, IoT paling erat hubungannya dengan komunikasi machine-to-machine (M2M) di bidang manufaktur dan listrik, perminyakkan, dan gas. Produk dibangun dengan kemampuan komunikasi M2M yang sering disebut dengan sistem cerdas atau "smart". Sebagai contoh yaitu smart kabel, smart meter, smart grid sensor. Defenisi lain dari IoT adalah menghubungkan alat pendeteksi dan penggerak yang menyediakan kemampuan untuk berbagi informasi lintas platform melalui kerangka kerja terpadu, mengembangkan gambaran operasi umum untuk memungkinkan aplikasi inovatif. Hal ini dicapai dengan penginderaan, analisis data dan representasi informasi yang realtime, analisis data dan representasi informasi dengan komputasi awan sebagai kerangka pemersatunya[26]. Untuk memenuhi persyaratan konektivitas baru dari segmen IoT yang mapan, ada kebutuhan 
akan standar baru yang akan membahas hal berikut: 1) biaya perangkat rendah; 2) meningkatkan masa pakai baterai; 3) peningkatan cakupan; dan 4) dukungan untuk sejumlah besar koneksi IoT[27].

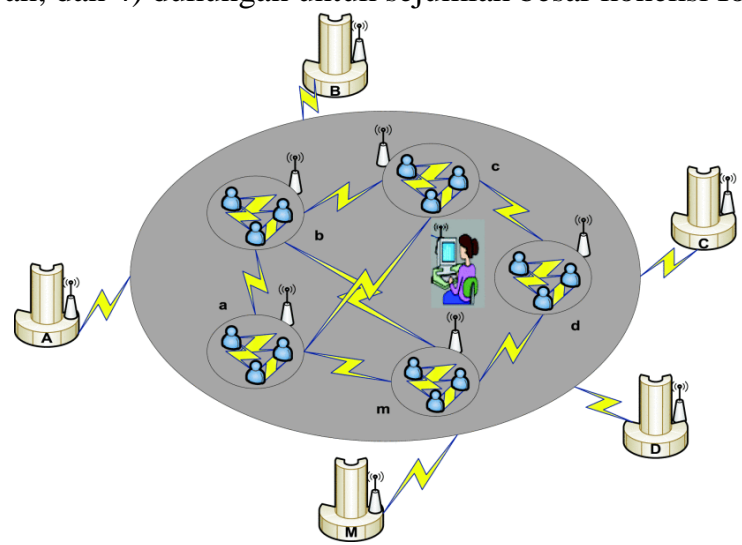

Gambar 3 : Interoblility System[27]

Layanan data sensor kolaboratif bermanfaat untuk berbagai aplikasi termasuk robotika, medis, industri dan militer. Analisis kolaboratif sensor dapat memperbaiki masalah teknis seperti verifikasi data sensor atau pengurangan transmisi data[28].

\section{E. Big Data}

Kemajuan terbaru dalam sensor jaringan berskala besar teknologi dan pertumbuhan eksplosif dalam komputasi data yang besar telah memungkinkan penerapan aplikasi baru secara cerdas ekosistem kota[27]. Secara realtime organisasi mengumpulkan data dari berbagai sumber, termasuk transaksi bisnis, media sosial dan informasi dari sensor atau mesin akan meningkatkan volume. Kecepatan Aliran data harus ditangani dengan secara cepat dan tepat bisa melalui hardware maupun software. Teknologi hardware seperti tag RFID, sensor pintar lainnya juga dibutuhkan untuk menangani data yang real-time. Variasi Data yang dikumpulkan mempunyai format yang berbeda-beda. Mulai dari yang terstruktur, data numerik dalam database tradisional, data dokumen terstruktur teks, email, video, audio, transaksi keuangan dan lain-lain[29].

Ketika organisasi mampu menggabungkan jumlah data besar yang dimilikinya dengan analisis bertenaga tinggi, organisasi dapat menyelesaikan tugas-tugas yang berhubungan dengan bisnis seperti:

- Menentukan akar penyebab kegagalan untuk setiap masalah bisnis.

- Menghasilkan informasi mengenai titik penting penjualan berdasarkan kebiasaan pelanggan dalam membeli.

- $\quad$ Menghitung kembali seluruh risiko yang ada dalam waktu yang singkat.

- $\quad$ Mendeteksi perilaku penipuan yang dapat mempengaruhi organisasi.

\section{METODOLOGI}

Paper ini menerapkan metodologi kajian literatur (literature review) untuk membangun konsep model penerapan artificial intelligence pada smart government, dan mengusulkan pendekatan terhadap desain penelitian.

Kajian penelitian ini menerapkan metodologi tersebut dalam 2(dua) tahap. Tahap pertama, melakukan studi literatur mengenai penelitian-penelitian yang berkaitan dengan penelitian penelitian kecerdasan buatan yang telah diterapkan pada sebuah kota atau pada penelitian tertentu. Hasil dari tahapan ini adalah state of the art penelitian penerapan kecerdasan buatan pada smart government berdasarkan penelitian-penelitian sebelumnya. Hasil dari tahapan ini adalah model kecerdasan buatan yang bisa digunakan untuk mempermudah analisis kota dengan menggunakan kecerdasan buatan.

\section{HASIL KAJIAN}

Penelitian yang mengambil tema kecerdasan buatan sangat banyak tetapi hanya pada sub tema tertentu dan dalam skala yang lebih sempit dan belum banyak mengambil domain pemerintahan secara umum. Berdasarkan kajian pada survey paper dapat dikelompokkan menjadi beberapa tema berdasarkan teknik artificial intelligence pada government yaitu searching-reasoning[30], searching-reasoning-planning[31], searching-reasoningplanning[32], planning[33][34], searching-planning[35][36], searching-reasoning-planning-learning[37], searching-reasoning-planning[38][39][40]. 
Berikut ini tabel pengelompokan penelitian tentang artificial intelligence pada instansi pemerintah berdasarkan teknik kecerdasan buatan.

Table 1 : Penelitian AI berdasarkan teknik yang digunakan

\begin{tabular}{|l|l|}
\hline Teknik & Penelitian \\
\hline Searching, reasoning & {$[30]$} \\
\hline Searching, reasoning, learning & {$[31]$} \\
\hline Searching, reasoning, planning & {$[32]$} \\
\hline Planning & {$[33][34]$} \\
\hline Searching, Planning & {$[35][36]$} \\
\hline $\begin{array}{l}\text { Searching, reasoning, planning, } \\
\text { learning }\end{array}$ & {$[37]$} \\
\hline Searching, reasoning, planning & {$[38][39][40]$} \\
\hline
\end{tabular}

Berikut ini tabel pengelompokan penelitian sebelumnya berdasarkan penggunaan metode kecerdasan buatan.

Table 2 : Penelitian AI berdasarkan method

\begin{tabular}{|l|l|}
\hline Metode & Penelitian \\
\hline NLP, Chatbot & {$[30]$} \\
\hline ANN & {$[32][34][35][33]$} \\
\hline ANN + KNN + Backpropagation & {$[36]$} \\
\hline ANN + Auto regresion Algorithm & {$[38]$} \\
\hline Machine Learning & {$[39]$} \\
\hline Deap Learning & {$[37]$} \\
\hline
\end{tabular}

Berikut ini pengelompokan penelitian berdasarkan penelitian selanjutnya.

Table 3 : Penelitian Berdasarkan penelitian selanjutnya

\begin{tabular}{|l|l|}
\hline $\begin{array}{l}\text { Pengembangan } \\
\text { Penelitian }\end{array}$ & Penelitian \\
\hline $\begin{array}{l}\text { Perluasan dalam domain } \\
\text { government }\end{array}$ & {$[30][33][34][36][37]$} \\
\hline $\begin{array}{l}\text { Peningkatan akurasi dan } \\
\text { efisiensi }\end{array}$ & {$[31][35][38][39]$} \\
\hline $\begin{array}{l}\text { Forcasting dengan big } \\
\text { data }\end{array}$ & {$[32][40]$} \\
\hline
\end{tabular}

Penelitian kecerdasan buatan pada domain pemerintah terakhir dilakukan oleh satu dkk[30] yang mengintegrasikan aplikasi berbasis chatbot, tetapi pada penelitian tersebut belum menyentuh keseluruhan aspek dan chatbot yang dihasilkan untuk keperluan konsumen bukan untuk pemerintah. Pada penelitian tersebut menggunakan pemrosesan bahasa alami yang terdapat dalam file artificial intelegence markup language(AIML). AIML menggambarkan sekelompok objek data yang dikenal sebagai objek AIML dan menggambarkan perilaku program dalam menangani objek-objek ini. Perilaku ini adalah corpus dari keseluruhan sistem chat[41]. Semua penelitian pada survey paper ini menggunakan artificial neural network sebagai metode penyelesaian permasalahannya dan digabungkan dengan metode-metode lainnya.

Penelitian smart city yang didalamnya terdapat egoverment yang telah dilakukan sc-cic ITB dalam smart government telah membuat intergasi smart system platform yang mengintegrasikan seluruh data dalam sebuah platform dengan gambar sebagai berikut : 


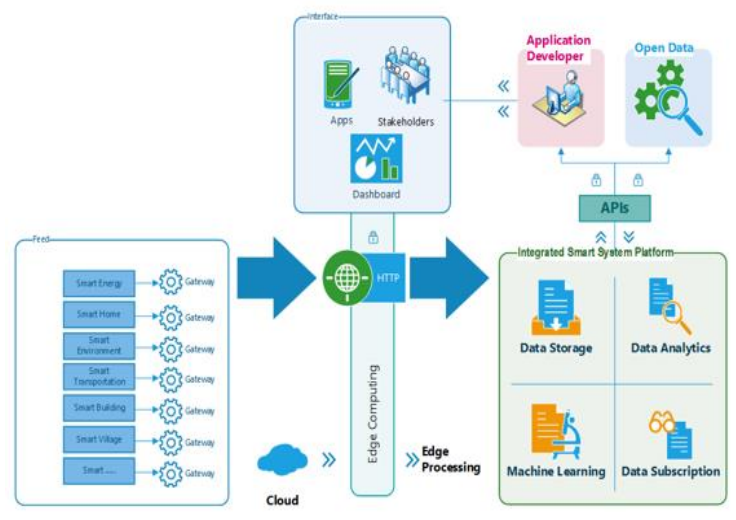

Gambar 4 : Integrasi sistem di smart city

Dalam pengembangannya pemroosessan data secara realtime untuk menampilkan analiss kota memerlukan kecerdasan buatan untuk dapat melakukan pencarian, pemahaman, perencanaan dan pembelajaran. Dalam pengembangan smart system platform digambarkan sebagai berikut :

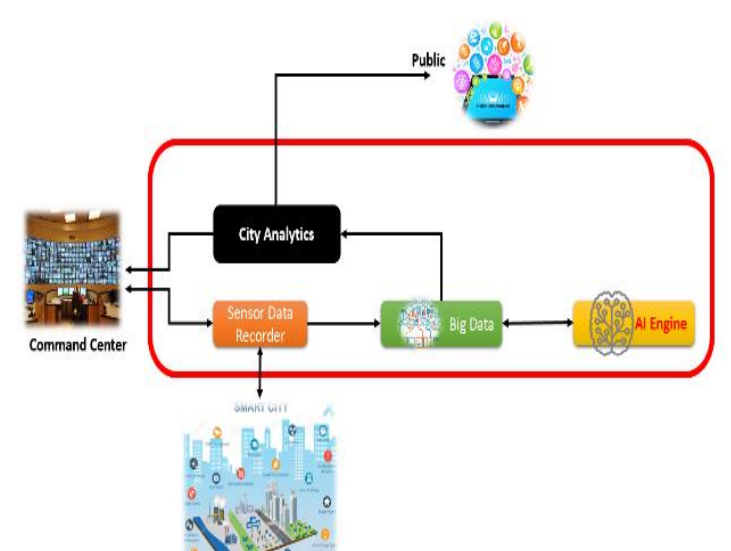

Gambar 5 : Kecerdasan Buatan dalam Smart City

\section{KESIMPULAN}

Dalam paper ini, kami telah melakukan kajian penelitian mengenai artificial intelligence pada smart government yang dimulai dengan mengklasifikasikan teknik kecerdasan buatan dalam penyelesaian permasalahan di pemerintah secara cerdas. Penelitian yang dapat dilanjutkan adalah dengan memperluas domain di government, peningkatan akurasi dan efisiensi, dan perencanaan dengan integrasi Big Data. Beberapa penelitian menyelesaikan bagian kecil dari permasalahan yang ada pada pemerintah. Melalui paper ini dapat meneruskan penelitian yang dapat diteruskan dari hasil-hasil penelitian yang sudah ada.

\section{REFERENSI}

[1] R. Petrolo, V. Loscri, and N. Mitton, "Cyber-Physical Objects as Key Elements for a Smart CyberCity," Manag. Cyber Phys. Objects Futur. Internet Things, pp. 31-49, 2016.

[2] Saluky, "Development of Enterprise Architecture Model for Smart City," ITEJ (Information Technol. Eng. Journals), vol. 2, no. 2, 2017.

[3] M. Wilson, "By 2050, 70\% Of The World's Population Will Be Urban. Is That A Good Thing?," Fast Company, 2012. [Online]. Available: https://www.fastcodesign.com/1669244/by-2050-70-of-theworlds-population-will-be-urban-is-that-a-good-thing.

[4] M. Batty, K. W. Axhausen, F. Giannotti, A. Pozdnoukhov, and A. Bazzani, "Smart Cities of the future," Eur. Phys. J., vol. 518, pp. 481-518, 2012.

[5] S. El Mendili, Y. El Bouzekri El Idrissi, and N. Hmina, "Benchmarking study on smart city data analytics,” 2016 4th IEEE Int. Colloq. Inf. Sci. Technol., pp. 841-846, 2016. 
[6] C. Persson, G. Picard, and F. Ramparany, "A Multi-Agent Organization for the Governance of Machine-to-Machine Systems,” ACM Int. Conf. Web Intell. Intell. Agent Technol., pp. 421-424, 2011.

[7] I. L. Jeannette Chin, Vic Callaghan, "Understanding and Personalising Smart City Services Using Machine Learning, the Internet-of-Things and Big Data," 2017 IEEE 26th Int. Symp. Ind. Electron., pp. 2050-2055, 2017.

[8] S. A. Victor Callaghan, James Miller, Roman Yampolskiy, The Technological Singularity Managing the Journey. Springer-Verlag Berlin Heidelberg, 2017.

[9] M. Kubat, An Introduction to Machine Learning. Springer, 2015.

[10] T. Wuest, D. Weimer, C. Irgens, K. Thoben, T. Wuest, D. Weimer, C. Irgens, and K. Thoben, "Machine learning in manufacturing : advantages, challenges , and applications," Prod. Manuf. Res., vol. 3277, no. November 2017, pp. 1-23, 2016.

[11] George F Luger, Artificial Intelligence : Structures and Strategies for Complex Problem Solving, vol. 5. 2005.

[12] H. Mehr, H. Ash, and D. Fellow, "Artificial Intelligence for Citizen Services and Government," Ash Cent. Democr. Gov. Innov. Harvard Kennedy Sch., no. August, p. pp 1-12, 2017.

[13] J. Yang, Y. Chen, W. Huang, and Y. Li, "Survey on Artificial Intelligence for Additive Manufacturing," 2017 23rd Int. Conf. Autom. Comput., no. September, pp. 7-8, 2017.

[14] S. Mathur, "Smart City- A Gateway For Artificial Intelligence In," IEEE Students' Conf. Electr. Electron. Comput. Sci. Smart, 2016.

[15] R. G. Hollands and R. G. Hollands, "Will the real smart city please stand up?," City Anal. urban trends, Cult. theory, policy, action, no. April 2013, pp. 37-41, 2008.

[16] R. Giffinger, R., Fertner, C., Kramar, H., Kalasek and E. Pichler-Milanović, N., \& Meijers, "Smart cities Ranking of European medium-sized cities," Vienna, Austria Cent. Reg. Sci. (SRF), Vienna Univ. Technol., no. October, 2007.

[17] R. E. Hall, "The vision of a Smart City," Proc. 2nd Int. Life Ext. Technol. Work., 2000.

[18] C. Harrison, B. Eckman, R. Hamilton, and P. Hartswick, "Foundations for Smarter Cities," IBM J. Res. Dev., vol. 54, no. 4, pp. 1-16, 2010.

[19] D. Washburn, U. Sindhu, S. Balaouras, R. A. Dines, N. M. Hayes, and L. E. Nelson, "Helping CIOs Understand 'Smart City' Initiatives," 2010.

[20] H. Chourabi, J. R. Gil-garcia, T. A. Pardo, H. J. Scholl, S. Walker, and K. Nahon, "Understanding Smart Cities : An Integrative Framework," Hawaii Int. Conf. Syst. Sci. Underst., 2012.

[21] J. Von Lucke, "Smart Government - The Potential of Intelligent Networking in Government and Public Administration," Conf. E-Democracy Open Gov., pp. 137-144, 2016.

[22] S. Hatsu and E. K. Ngassam, "An Integrated Framework for Benchmarking e-Government Projects," Conf. Proc. Paul Cunningham Miriam Cunningham IIMC Int. Inf. Manag. Corp., pp. 1-9, 2017.

[23] R. Heeks and R. Heeks, "Information Systems and Developing Countries: Failure, Success, and Local Improvisations," Inf. Soc. An Int. J., no. December 2012, pp. 37-41, 2011.

[24] S. Zhong, L. Zhang, H. Chen, H. Zhao, and L. Guo, "Study of the Patterns of Automatic Car Washing in the Era of Internet of Things," 2017 31st Int. Conf. Adv. Inf. Netw. Appl. Work., pp. 82-86, 2017.

[25] B. Bharadwaj, M. Kumudha, G. C. N, and G. Chaithra, "Automation of Smart Waste Management Using IoT to Support 'Swachh Bharat Abhiyan' - a Practical Approach,” 2017 2nd Int. Conf. Comput. Commun. Technol., pp. 318-320, 2017.

[26] L. Liu, “Things for Healthcare," Smart Cities Conf. (ISC2), 2017 Int., 2017.

[27] L. Ang, S. Member, K. P. Seng, A. M. Zungeru, and G. K. Ijemaru, "Big Sensor Data Systems for Smart Cities,” IEEE Internet Things J., vol. 4, no. 5, pp. 1259-1271, 2017.

[28] J. Yoon, "ANN-based Collaborative Sensor Calibration and GA-approach to Sensor Mutation Management," 2017 6th IIAI Int. Congr. Adv. Appl. Informatics, pp. 897-902, 2017.

[29] S. Chen, K. Wang, C. Zhao, H. Zhang, S. Member, and Y. Sun, "Accelerated Distributed Optimization Design for Reconstruction of Big Sensory Data,” EEE Internet Things J., vol. 4, no. 5, pp. 1716-1725, 2017.

[30] M. S. Satu, M. H. Parvez, and Shamim-Al-Mamun, "Review of integrated applications with AIML based chatbot," 1st Int. Conf. Comput. Inf. Eng. ICCIE 2015, pp. 87-90, 2016.

[31] G. W. G. Wei, X. X. X. Xhang, X. Z. X. Zhang, and Z. H. Z. Huang, "Research on E-government Information Security Risk Assessment - Based on Fuzzy AHP and Artificial Neural Network Model," Netw. Distrib. Comput. (ICNDC), 2010 First Int. Conf., pp. 4-7, 2010.

[32] N. Citroen and M. Ouassaid, "Moroccan Long Term Electricity Demand Forecasting Using Wavelet Neural Networks," 2015 3rd Int. Renew. Sustain. Energy Conf., pp. 1-7, 2015.

[33] H. Zhou, C. Noble, and J. Cotter, “A Big Data Based Intelligent Decision Support System for 
Sustainable Regional Development,” 2015 IEEE Int. Conf. Smart City/SocialCom/SustainCom, pp. 822826, 2015.

[34] O. A. Olanrewaju and C. Mbohwa, "Evaluating factors responsible for energy consumption: Connection weight approach,” 2016 IEEE Electr. Power Energy Conf. EPEC 2016, pp. 1-5, 2016.

[35] K. Chimanga, J. Kalezhi, and P. Mumba, "Application of best first search algorithm to demand control," IEEE PES PowerAfrica Conf. PowerAfrica 2016, pp. 51-55, 2016.

[36] M. W. Rahman and M. Gavrilova, "Overt Mental Stimuli of Brain Signal for Person Identification," Proc. - 2016 Int. Conf. Cyberworlds, CW 2016, pp. 197-203, 2016.

[37] S. Sudha, "An Automatic Classification Method for Environment Friendly Waste Segregation Using Deep Learning," no. Tiar, pp. 65-70, 2016.

[38] S. K. Babu, "Framework for Predictive Analytics as a Service using ensemble model," 2017 IEEE 7 th Int. Adv. Comput. Conf., pp. 121-128, 2017.

[39] K. Hu, V. Sivaraman, and H. Bhrugubanda, "SVR Based Dense Air Pollution Estimation Model Using Static and Wireless Sensor Network,” 2016 IEEE SENSORS, no. May, pp. 2-4, 2016.

[40] Y. Xu, Y. Zhu, and C. Author, "When Remote Sensing Data meet Ubiquitous Urban Data : FineGrained Air Quality Inference,” 2016 IEEE Int. Conf. Big Data (Big Data), pp. 1252-1261, 2016.

[41] Y. Wei and B. Sun, "Comparative Studies of AIML," 2016 3rd Int. Conf. Syst. Informatics (ICSAI 2016), no. Icsai, pp. 344-349, 2016. 